\title{
DIVERSITY AND UNCOMMON HPV TYPES IN HIV SEROPOSITIVE AND SERONEGATIVE WOMEN ATTENDING AN STI CLINIC
}

\author{
Adriana Tonani de Mattos ${ }^{1}$, Luciana Bueno de Freitas ${ }^{1}$, Bettina Moulin Coelho Lima ${ }^{2}$, Angélica Espinosa Miranda ${ }^{1}$, \\ Liliana Cruz Spano ${ }^{1,2 *}$
}

${ }^{1}$ Núcleo de Doenças Infecciosas, Universidade Federal do Espírito Santo, Vitória, ES, Brasil; ${ }^{2}$ Centro de Referência de DST/AIDS, Prefeitura Municipal de Saúde, Vitória, ES, Brasil; ${ }^{3}$ Departamento de Patologia, Centro de Ciências da Saúde, Universidade Federal do Espírito Santo, Vitória, ES, Brasil.

Submitted: June 30, 2010; Returned to authors for corrections: September 02, 2010; Approved: January 13, 2011.

\begin{abstract}
Given the causal relationship between specific types of HPV with cervical cancer and precursor lesions, it is important to identify the viral type involved. The aim of this study is to access the prevalence of HPV types in HIV seropositive and seronegative women. Accordingly, $77 \mathrm{HPV}$ positive cervical samples were obtained from 284 women (seropositive ( $\mathrm{n}=112)$ and seronegative $(\mathrm{n}=172)$ for HIV) who attended a Sexually Transmitted Infection clinic, in Vitoria, Southeastern Brazil. Viral DNA was amplified by PCR using MY09/MY11 degenerated primers and the genotyping was performed by Restriction Fragment Length Polymorphism. Seventy five out of the 77 HPV samples were genotyped: 6, 11, 13, 16, 18, 26, 31, 31b, 32, $33,34,35,52,53,55,56,58,59,61,62,64,66,71,81,83,84$. The most prevalent type was HPV16 followed by HPV types 6, 11 and 53. Fifty five percent and $45 \%$ belonged to high and low risk types, respectively. High risk types corresponded to 59\% and 54.5\% of the HPV detected in HIV seronegative and seropositive women, respectively. The uncommon HPV 13 type in cervical samples was also observed in this study. The oncogenic types were more common in the HIV seronegative samples and the number of cases with multiple infections was similar for the two groups. HPV typing is not only important clinically for the establishment of monitoring and treatment of a patient, it also provides knowledge of the viral types circulating in a population, which is of interest in the development of prevention and treatment programs for this disease.
\end{abstract}

Key words: Human papillomavirus (HPV); HIV seropositive and seronegative women; RFLP; genotyping; cervical secretion

\section{INTRODUCTION}

Human papillomaviruses (HPV) are major sexually transmitted infectious agents (2) and they are the second most common cause of cancer death among women; they are associated with cervical cancer in $99.7 \%$ of cases (28).

HPVs are classified into more than 100 types (33), nearly 40 of them cause anogenital infection (56) and they are divided

*Corresponding Author. Mailing address: Núcleo de Doenças Infecciosas, Universidade Federal do Espírito Santo, Vitória, ES.; Tel/Fax.: 55 27 3335.7297 / 55 27 3335.7290.; E-mail: 1spano.vix@terra.com.br 
into low risk (LR) or high risk (HR) according to their association with cervical cancer (29).

HPV infection is particularly burdensome for HIV-infected women as it is more difficult for them to eliminate the virus, which increases the risk of developing cervical dysplasia and cancer $(1,11$, 18, 34). Moreover, recent studies indicate a higher frequency of high risk types and a more persistent infection in HIV positive women, in opposition to low risk types found in HIV negative women, other than cases of co-infection $(14,25)$.

So, the aim of the present study is to determine the frequency of HPV types in HIV seropositive and seronegative women.

\section{MATERIAL AND METHODS}

\section{Cases and Samples}

This is a descriptive study using 284 cervical brush samples obtained from HIV seropositive $(n=112)$ and seronegative $(\mathrm{n}=172)$ women, from 14 to 51 years old (median 29 years old), attending a Sexually Transmitted Infection and AIDS (STI/AIDS) clinic in Vitoria, Brazil, in the period from March to December of 2006 (44). Participants were interviewed after providing informed consent. Enrolled participants underwent a gynecological evaluation and cervical scrape samples were collected for cytological analysis and HPV DNA polymerase chain reaction (PCR) as previously described by our group (27). Seventy seven HPV positive samples were genotyped in this study. From these, $43 \%(33 / 77)$ were from HIV seropositive women and 57\% (44/77) from HIV seronegative. Five out of the 77 samples were from women with cytological abnormalities; two and three of them from HIV seropositive and seronegative women, respectively. Seventy two samples were from women with normal cytology or benign cellular changes: three with low grade squamous intraepithelial lesions (SIL), one high grade SIL and one atypical squamous cells of undetermined significance (ASCUS).

\section{DNA extraction and polymerase chain reaction for HPV}

Viral DNA was extracted from the samples by the
QIAamp DNA Mini Kit TM (Qiagen, Hilden, Germany) according to the manufacturer's instructions or by the isothiocyanate guanidine and silica methodology (7). HPV DNA amplification was carried out in a final volume of 100 $\mu \mathrm{L}$, containing $2.5 \mathrm{U}$ of Taq DNA polymerase enzyme (Invitrogen, Brazil), $40 \mathrm{pmol}$ of each consensus primer MY09/11, $2.5 \mu \mathrm{L}$ of reaction buffer 10X (100 mM Tris- $\mathrm{HCl}$ $\mathrm{pH} 8.3,500 \mathrm{mM} \mathrm{KCl}), 1.5 \mathrm{mM}$ of $\mathrm{MgCl}_{2}$, and $200 \mu \mathrm{M}$ of each dNTP (2, 32), following a amplification program previously described (38). $\beta$-globin gene amplification was used as control for the extraction and DNA integrity.

The reactions were carried out in a Perkin Elmer CETUS Thermo Cycler and the amplicons, stained with $0.5 \mathrm{mg} / \mathrm{mL}$ ethidium bromide after electrophoresis on $1.5 \%$ agarose gel, were observed by a gel imaging system (Bio-Imaging Systems $\left.{ }^{\mathrm{TM}}\right)$. All precautions to avoid cross contamination and PCR inhibition were observed. Water was included for all extraction and amplification procedures as a negative control.

\section{HPV genotyping by Restriction Fragment Length Polymorphism}

HPV genotyping was carried out using the RFLP methodology, which is able to detect 44 HPV genital types, as described by Bernard et al. (4). Accordingly, the product of MY09/11 amplification, quantified by spectrophotometer NanoDrop ${ }^{\mathrm{TM}}$ (NanoDrop Technologies), was digested overnight in a separate reaction containing twenty units of each digestion enzyme BamH I, Dde I, Hae III, Hinf I, Pst I, RsaI and Sau3A I (Promega, Madison, WI, USA). The fragments were revealed by electrophoresis on $3 \%$ agarose gel stained by ethidium bromide, as mentioned before, or on acrylamide gel stained by silver nitrate, and compared with the fragments described by Bernard et al. (4) for analyses of the HPV type.

\section{ETHICS}

All experiments were performed in compliance with 
relevant laws and institutional guidelines and in accordance with ethical standards. The researchers obtained approval for the study from the Ethical Research Committee of the Health Science Center of the Federal University of Espírito Santo. All the women gave their free and informed consent.

\section{RESULTS}

To determine the HPV infectious type, the HPV DNA of all samples was amplified by PCR. The RFLP technique genotyped 75 out of the 77 samples, the two remaining samples showed indeterminate types. Twenty six different types were found, among them the most prevalent were types $16(20 \%)$, followed by types 6 (12\%), 11 and 53 (10.6\%) (Figure 1).

In HIV positive women 18 different HPV types were detected, the most prevalent types were 16 (18.2\%), 6, 11 and 31 (12\% each), while in HIV negative women 19 different types were found; and the most frequent were HPV16 (20.5\%), 6 and 53 (11.4\% each). Among the HPV types determined, $55 \%(n=44)$ were high risk and $45 \%(n=36)$ were low risk types, including the types found in co-infection cases. Highrisk HPV types were present in low SIL, high SIL and ASCUS out of the five cases with cytological abnormalities (Table 1).

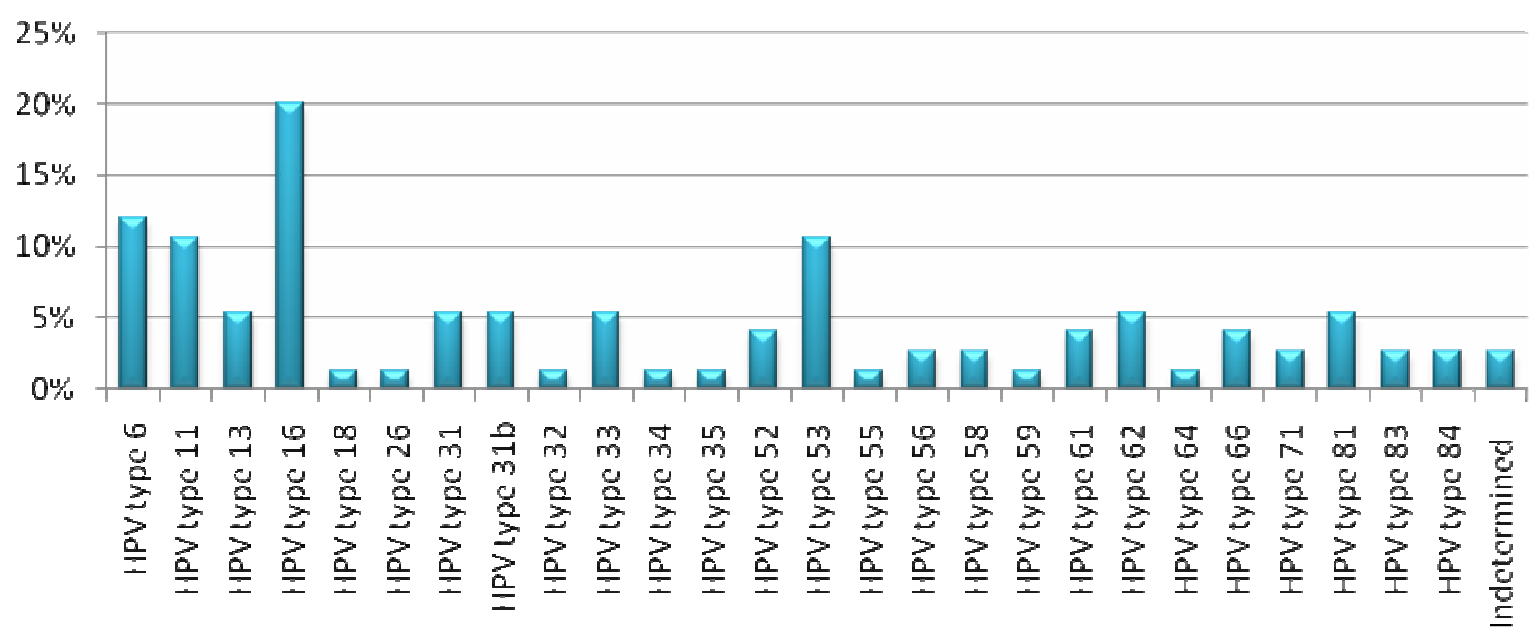

Figure 1. Prevalence of the HPV types identified by Restriction Fragment Length Polymorphism in HIV seropositive and seronegative women, attending the STD-Aids clinic in Vitória, Southeastern Brazil, between March and December 2006.

Table 1. Cytologic abnormalities and HPV type involved in HIV seropositive and seronegative women, attending the STD-Aids clinic in Vitória, Southeastern Brazil, between March and December 2006.

\begin{tabular}{lll}
\hline Cytology & HPV types* & HIV \\
\hline Low SIL & $6(\mathrm{LR})$ & Negative \\
Low SIL & $33(\mathrm{HR})$ & Negative \\
Low SIL & $13(\mathrm{LR})$ & Negative \\
High SIL & $66(\mathrm{HR})$ & Positive \\
ASCUS & $31(\mathrm{HR})$ & Positive
\end{tabular}

LR: Low Risk; HR: High Risk 
HIV seronegative women showed $59 \%$ of high risk types (26/44) and HIV seropositive women 54.5\% (18/33). HPV types were not determined in two cases, both in HIV negative women. Thirteen cases of multiple infections were observed, seven of them occurred among HIV positive women. Out of the total, ten cases had two HPV types and three, three distinct HPV types. The genotypes observed in co-infection were: 6 , $11,13,16,26,31,33,52,53,55,56,61,62,71$ and 81 .

\section{DISCUSSION}

It is of great importance to establish the types of HPV circulating in different regions especially in order to be able to follow up the effectiveness of the quadrivalent and bivalent vaccines commercially available $(20,54)$. There are few studies concerning HPV types in the Espírito Santo region, and the studies that have been carried out employed a low number of samples (17) or used a PCR with specific primers targeting only seven distinct types (27). In contrast a larger number of samples were used in this study and the RFLP technique, which is able to detect 44 types of HPV that infect mucosa, was used.

The results obtained in this study revealed that $76 \%$ of the women would not be protected by the quadrivalent vaccine and $84 \%$ of them would not be protected by the bivalent vaccine, unless cross-protection with the closest phylogenetical HPVtype occurred. The cross-protection was described for HPV31 and HPV45, which are types related to HPV16 and HPV 18 (6). However, studies concerning cross protection are limited by the time and amplitude of vaccine usage compromising conclusions in this matter.

This study also describes a higher prevalence of the HPV16 type (16\%). Although different types of HPV show a variable geographic distribution (12), HPV16 is usually indicated as the most prevalent type in South America, Asia and Europe in general, as in Brazil (8, 9, 12, 39, 41, 43, 44, 52, 53). In Sub-Saharan Africa HPV16 was the second most prevalent (12) and in several other studies showed varied prevalence, but it is usually high $(15,25,35,46,55,47)$.

Studies had shown that HIV seropositive women are normally infected by high risk HPV types different from 16 and $18(47,23,25,26,31)$. However, the present study demonstrated HPV16 as the most prevalent type among both HIV positive and HIV negative women, which may be due to a regional distribution feature of this HPV type. Moreover, other studies such as Tanzi et al. (51) identified HPV 16 in HIV positive women as the most prevalent type among those with and without cytological alterations. The higher prevalence of HPV16 in HIV negative women has already been described, and this type accounts for $55 \%$ of cervical cancer cases in the world (48).

Since HIV infected women are susceptible to opportunistic infections, it is not surprising that HPV types are more prevalent in HIV-positive women (34). Also the vast majority of studies show that individuals infected with HIV have a higher prevalence of high-risk HPVs $(24,37,51)$. Minkoff et al. (36) reported a level of oncogenic types three times higher in HIV-positive women. However in the present study similar levels of HPV types were found in both populations, although slightly higher among HIV-negative women (59\% vs. $54.5 \%)$.

In HIV-infected women there is an increased risk of HPV infection and squamous intraepithelial lesions (SIL), the precursor of cervical cancer $(45,50)$. In this study, SIL cases were similar in HIV seropositive and seronegative women, a fact also observed by Luchters et al. in 2010 (30). Moreover the cases of abnormalities were infected by only one HPV type, a not uncommon fact. Fernandes et al., 2008 (16) reported single infection in more than a half of the cases with abnormalities. Samples from women with cervical lesions were infected similarly with high risk and low risk HPV types. It is interesting that many cases of normal cytology were infected by high risk HPV types. These women have a greater chance of developing persistent infection, which can remain asymptomatic for an undetermined period. 
The most prevalent types after HPV16 were $6(9.7 \%), 11$ and $53(8.6 \%)$, which are normally present in Brazilian studies $(8,9,19,25,39,41,43,44,52)$, but less frequent in other countries like South Africa, Jamaica, Australia and Ireland (35, $55,47,49)$.

The rate of undetermined types found in this study was low $(2.2 \%)$, which is due to the RFLP technique used that is able to identify 44 of the 50 types of HPV that infect the mucosa. Other studies using the same methodology found rates of $4.3 \%$ to $36.4 \%$ of undetermined types $(17,40,41)$, while the percentage of these undetermined types varied from $4.2 \%$ to $45.1 \%$ with the following techniques: AMPLICOR associated to Linear Array, Dot Blot, Linear Array, Kit Papillomavirus Clinical Arrays ${ }^{\circledR}$, PCR with specific primers $(15,21,27,46$, $55)$.

Unexpectedly, in this study HPV13 was found in $4.3 \%$ of the samples. This is a rare low risk type, related to HPV6 (13, 21), well-known to be associated with focal epithelial hyperplasia (3) and unusually found in studies infecting the genital tract. Illades-Aguiar et al. (22) found this type in $0.1 \%$ of low grade squamous intraepithelial lesion samples, in Mexico. These low percentages of HPV13 could be partially explained by the fact that various techniques of genotyping of HPV are not able to determine this type or due to the uncommon distribution of this type. Unfortunately, the cervical secretions in our study were not enough to sequence those samples to confirm the presence of this HPV type.

HPV type 32 was found in $1 \%$ of the samples in the present study and, similar to HPV13, is a major cause of focal hyperplasia epithelial (3). On the other hand, this type is more commonly found infecting the genital tract $(10,21,22,42)$, including in the region of this study (17).

The present study showed a similar number of coinfection cases in HIV-positive and HIV-negative women (7 versus 6) and the maximum number of types found was three. In contrast Levi et al. (25) demonstrated in their study $78.9 \%$ of multiple infections with up to 10 different types of HPV in
HIV-positive women. Other studies show similarly large number of multiple infections in HIV-positive women $(14,51)$.

Further studies are extremely important to establish the HPV type in different regions, not only for following up the effectiveness of vaccines released for sale, but also to determine the best prognosis and monitoring of these women, as well as defining specific health policies for the female population infected with HIV.

\section{ACKNOWLEDGEMENTS}

The authors would like to thank Fundação de Apoio à Ciência e Tecnologia do Espírito Santo (FACITEC) and Fundação de Apoio à Pesquisa do Espírito Santo (FAPES) for their financial aid.

\section{REFERENCES}

1. Adachi, A.; Fleming, I.; Burk, R.D.; Ho, G.Y.; Klein, R.S. (1993). Women with human immunodeficiency vírus infection and abnormal Papanicolaou smears: a prospective study of colposcopy and clinical outcome. Obstet. Gynecol. 81(3), 372-377

2. Bauer, H.M.; Ting, Y.; Greer, C.E.; Chambers, J.C.; Tashiro, C.J.(1991). Genital human papillomavirus infection in female university students as determined by a PCR-based method. JAMA. 265 (4), 472-477.

3. Beaudenon, S.; Praetorius, F.; Kremsdorf, D.; Lutzner, M.; Worsaae, N.; Pehau-Arnaudet, G.; Orth, G. (1987). A new type of human papillomavirus associated with oral focal epithelial hyperplasia. J. Invest. Dermatol. 88 (2), 130-135.

4. Bernard, H.U.; Chan, S.Y.; Manos, M.M.; Ong, C.; Villa L.L.; Delius, H.; Peyton, C.L.; Bauer, H.M.; Wheeler, C.M. (1994). Identification and assessment of known and novel Humam Papillomaviruses by polymerase chain reaction amplification, restriction fragment length polymorphisms, nucleotide sequence, and phylogenetic algorithms. J Infec Dis. 170 (5), 1077-1085.

5. Blossom, D.B.; Beigi, R.H.; Farrell, J.J.; Mackay, W.; Qadadri, B.; Brown, D.R.; Rwambuya, S.; Walker, C.J.; Kambugu, F.S.; AbdulKarim, F.W.; Whalen, C.C.; Salata, R.A. (2007). Human papillomavirus genotypes associated with cervical cytologic abnormalities and HIV infection in Ugandan women. J. Med. Virol. 79 (6), 758-765.

6. Bonanni, P.; Boccalini, S.; Bechini, A. (2009). Efficacy, duration of immunity and cross protection after HPV vaccination: a review of the 
evidence. Vaccine. 27 Suppl 1, A46-53.

7. Boom, R.; Sol, C.; Salimans, M.M.; Jansen, C.L.; Wertheim-Van Dillen, P.M.; Van Der Noordaa, J. (1990). Rapid and simple method for purification of nucleic acids. J. Clin. Microbiol. 28 (3), 495-503.

8. Camara, G.N.L.; Cerqueira, D.M.; Oliveira, A.P.G.; Silva, E.O.; Carvalho, L.G.S.; Martins, C.R.F. (2003). Prevalence of Human Papillomavirus Types in Women with Pre-neoplastic and Neoplastic Cervical Lesions in the Federal District of Brazil. Mem. Inst. Oswaldo Cruz. 98 (7), 879-883.

9. Campos, E.A.; Simões, J.A.; Rabelo-Santos, S.H.; Sarian, L.O.; Pitta, D.R.; Levi, J.E.; Derchain, S. (2008). Recovery of DNA for the detection and genotyping of human papillomavirus from clinical cervical specimens stored for up to 2 years in a universal collection medium with denaturing reagent. J. Virol. Methods. 147 (2), 333-337

10. Cerqueira, D.M.; de S Moraes, D.; Camara, G.N.; Amaral, F.A.; Oyama, C.N.; dos Santos, M.Q.; Martins, C.R. (2007). High HPV genetic diversity in women infected with HIV-1 in Brazil. Arch. Virol. 152 (1), $75-83$.

11. Chiasson, M.A.; Ellerbrock, T.V.; Bush, T.J.; Sun, X.W.; Wright, Jr T.C. (1997). Increased prevalence of vulvovaginal condyloma and vulvar intraepithelial neoplasia in women infected with the human immunodeficiency vírus. Obstet. Gynecol. 89 (5 Pt 1), 690-694.

12. Clifford, G.M.; Gallus, S.; Herrero, R.; Muñoz, N.; Snijders, P.J.; Vaccarella, S.; Anh, P.T.; Ferreccio, C.; Hieu, N.T.; Matos, E.; Molano, M.; Rajkumar, R.; Ronco, G.; de Sanjosé, S.; Shin, H.R.; Sukvirach, S.; Thomas, J.O.; Tunsakul, S.; Meijer, C.J.; Franceschi, S.; IARC HPV Prevalence Surveys Study Group (2005). Worldwide distribution of human papillomavirus types in cytologically normal women in the International Agency for Research on Cancer HPV prevalence surveys: a pooled analysis. Lancet. 366 (9490), 991-998.

13. de Villiers, E.M.; Fauquet, C.; Broker, T.R.; Bernard, H.U.; zur Hausen, H. (2004). Classification of papillomaviruses. Virology. 324 (1), 17-27.

14. Desruisseau, A.J.; Schmidt-Grimminger, D.; Welty, E. (2009). Epidemiology of HPV in HIV-ositive and HIV-negaive fertile women in Cameroon, West Africa. Infect. Dis. Obstet. Gynecol. 810596, 1-6.

15. Dutra, I.; Santos, M.R.; Soares, M.; Couto, A.R.; Bruges-Armas, M.; Teixeira, F.; Monjardino, L.; Hodgson, S.; Bruges-Armas, J. (2008). Characterization of human papillomavirus (HPV) genotypes in the Azorean population, Terceira island. Infect. Agent. Cancer. 21, 3-6.

16. Fernandes, T.A.A.M.; Meissner, R.V.; Bezerra, L.F.; Azevedo, P.R.M.; Fernandes, J.V (2008). Human Papillomavirus infection in women attended at a cervical cancer screening service in Natal, Brazil. BJM. 39, 573-578.

17. Freitas, L.B.; Pereira, C.C.; Checon, R.; Leite, J.P.; Nascimento, J.P.; Spano, L.C. (2009). Adeno-associated virus and human papillomavirus types in cervical samples of pregnant and non-pregnant women. Eur. $J$. Obstet. Gynecol. Reprod. Biol. 145 (1), 41-44.
18. Frutcher, R.G.; Maiman, M.; Arrastia, C.D.; Matthews, R.; Gates, E.J.; Holcomb, K. (1998). Is HIV infection a risk factor for advanced cervical câncer? J. Acquir. Immune. Defic. Syndr. Hum. Retrovirol. 18 (3), 241 245 .

19. Grinsztejn, B.; Veloso, V.G.; Levi, J.E.; Velasque, L.; Luz, P.M.; Friedman, R.K.; Andrade, A.C.; Moreira, R.I.; Russomano, F.; Pilotto, J.H.; Bastos, F.I.; Palefsky, J. (2009). Factors associated with increased prevalence of human papillomavirus infection in a cohort of HIVinfected Brazilian women. Int. J. Infect. Dis. 13 (1), 72-80.

20. Harper, D.M.; Franco, E.L.; Wheeler, C.M.; Moscicki, A.B.; Romanowski, B.; Roteli-Martins, C.M.; Jenkins, D.; Schuind, A.; Costa Clemens, S.A.; Dubin, G.; HPV Vaccine Study group (2006). Sustained efficacy up to 4.5 years of a bivalent L1 virus-like particle vaccine against human papillomavirus types 16 and 18: follow-up from a randomised control trial. Lancet. 367 (9518), 1247-1255.

21. Herrero, R.; Castle, P.E.; Schiffman, M.; Bratti, M.C.; Hildesheim, A.; Morales, J.; Alfaro, M.; Sherman, M.E.; Wacholder, S.; Chen, S.; Rodriguez, A.C.; Burk, R.D. (2005). Epidemiologic profile of typespecific human papillomavirus infection and cervical neoplasia in Guanacaste, Costa Rica. J. Infect. Dis. 191 (11), 1796-1807.

22. Illades-Aguiar, B.; Alarcón-Romero, L.D.; Antonio-Véjar, V.; ZamudioLópez, N.; Sales-Linares, N.; Flores-Alfaro, E.; Fernández-Tilapa, G.; Vences-Velázquez, A.; Muñoz-Valle, J.F.; Leyva-Vázquez, M.A. (2010). Prevalence and distribution of human papillomavirus types in cervical cancer, squamous intraepithelial lesions, and with no intraepithelial lesions in women from Southern Mexico. Gynecol. Oncol. 117 (2), 291296.

23. La Ruche, G.; You, B.; Mensah-Ado, I.; Bergeron, C.; Montcho, C.; Ramon, R.; Touré-Coulibaly, K.; Welffens-Ekra, C.; Dabis, F.; Orth, G. (1998). Human papillomavirus and human immunodeficiency virus infections: relation with cervical dysplasia-neoplasia in African women. Int. J. Cancer. 76 (4), 480-486.

24. La Ruche, G.; Leroy, V.; Mensah-Ado, I.; Ramon, R.; You, B.; Bergeron, C.; Mothebesoane-Anoh, S.; Touré-Coulibaly, K.; Dabis, F. (1999). Shortterm follow up of cervical squamous intraepithelial lesions associated with HIV and human papillomavirus infections in Africa. Int. J. STD AIDS. 10 (6), 363-368.

25. Levi, E.J.; Kleter, B.; Quint, G.V.; Fink, C.S.; Canto, L.M.; Matsubara, R.; Linhares, I.; Segurado, A.; Vanderborght, B.; Neto, J.E.; Doorn, L.J. (2002). High prevalence of Human Papilloma vírus (HPV) infections and high frequency of multiple HPV genotypes in human immunodeficiency virus-infected women in Brazil. J. of Clinical. Microbiology. 40 (9), 3341-3345.

26. Levi, J.E.; Fernandez, S.; Tateno, A.F.; Lima, L.P.; Eluf-Neto, J.; Pannuti, C.S. (2004). Presence of multiple human papillomavirus types in cervical samples from HIV-infected women. Gynecol. Oncol. 92 (1), 225-231. 
27. Lima, B.M.C.; Golub, J.E.; Mattos, A.T.; Freitas, L.B.; Spano, L.C.; Miranda, A.E. (2009). Human Papillomavirus in Women With and Without HIV-1 Infection Attending an STI Clinic in Vitoria, Brazil. J. Int. Assoc. Physicians AIDS Care. 8 (5), 286-290.

28. Lockwood-Rayermann, S.; Mcintyre, S.J. (2009). Understanding HPV disease and prevention: a guide for school nurses. J. Sch. Nurs. 25(4), 261-269.

29. Lowy, D.R.; Howley, P.M. (2001). Papillomavirus. In: Fields Virology (eds 4). Lippincott Williams \&Wilkins, Philadelphia, USA, CD-rom.

30. Luchters, S.M.; Vanden, B.D.; Chersich, M.F.; Nel, A., Delva, W.; Mandaliya, K.; Depuydt, C.E.; Claeys, P.; Bogers, J.P.; Temmerman, M (2010). Association of HIV infection with distribution and viral load of HPV types in Kenya: a survey with 820 female sex workers. BMC Infect Dis. 26, 10-18.

31. Luque, A.E.; Jabeen, M.; Messing, S.; Lane, C.A.; Demeter, L.M.; Rose, R.C.; Reichman, R.C. (2006). Prevalence of human papillomavirus genotypes and relate abnormalities of cervical cytological results among HIV-1-infected women in Rochester, New York. J. Infect. Dis. 194 (4), 428-434.

32. Manos, M.M.; Ting, Y.; Wright, D.K.; Lewis, A.J.; Broker, T.R.; Wolinsky, S.M. (1989). The use of polymerase chain reaction amplifications for the detection of genital human papillomavirus. Cancer Cell. 7, 209-214.

33. Mausumi, B.; Showket, H.; Vilas, N. \& Bhudev, C. (2009). HPV \& HPV vaccination: Issues in developing countries. Indian J. Med. Res. 130 (3), 327-333.

34. McKenzie, N.D.; Kobetz, E.M.; Hnatyszyn, J.; Twiggs, L.B.; Lucci, J.A. (2009). Women with HIV are more commonly infected with non-16 and non-18 high-risk HPV types. Gynecol. Oncol. 116 (3), 572-577.

35. Menton, J.F.; Cremin, S.M.; Canier, L.; Horgan, M.; Fanning, L.J. (2009). Molecular epidemiology of sexually transmitted human papillomavirus in a self referred group of women in Ireland. Virol. J. 6, 112-118.

36. Minkoff, H.; Feldman, J.; DeHovitz, J.; Landesman, S.; Burk, R. (1998). A longitudinal study of human papillomavirus carriage in human immunodeficiency virus-infected and human immunodeficiency virusuninfected women. Am. J. Obstet. Gynecol. 178 (5), 982-986.

37. Motti, P.G.; Dallabetta, G.A.; Daniel, R.W.; Canner, J.K.; Chiphangwi, J.D.; Liomba, G.N.; Shah, K.V. (1996). Cervical abnormalities, human papillomavirus, and human immunodeficiency virus infections in women in Malawi. J. Infect. Dis. 173 (3), 714-717.

38. Oliveira, L.H.S.; Rodrigues, E.V.M.; Lopes, A.P.T.S.; Fernandes, A.P.; Cavalvanti, S.M.B.. (2003). HPV 16 detections in cervical lesions, physical state of viral DNA and changes in p53 gene. São Paulo Med J. 121, 67-71.

39. Oliveira, L.H.S.; Rosa, M.L.G.; Cavalcanti, S.M.B. (2008). Patterns of genotype distribution in multiple human papillomavirus Infections. Clin.
Microbiol. Infect. 14 (1), 60-65.

40. Oliveira, L.H.; Ferreira, M.D.; Augusto, E.F.; Melgaço, F.G.; Santos, L.S.; Cavalcanti, S.M.; Rosa, M.L. (2010). Human papillomavirus genotypes in asymptomatic young women from public schools in Rio de Janeiro, Brazil. Rev. Soc. Bras. Med. Trop. 43 (1), 4-8.

41. Paesi, S.; Serafini, E.P.; Barea, F.; Madi, S.R.C.; Echeverrigaray, S. (2009). High Prevalence of Human Papillomavirus Type 58 in Patients With Cervical Pre-malignant Lesions in Southern Brazil. J. Med. Virol. 81 (7), 1270-1275.

42. Palefsky, J.M.; Minkoff, H.; Kalish, L.A.; Levine, A.; Sacks, H.S.; Garcia, P.; Young, M.; Melnick, S.; Miotti, P.; Burk, R. (1999). Cervicovaginal human papillomavirus infection in human immunodeficiency virus-1 (HIV)-positive and high-risk HIV-negative women. J. Natl. Cancer Inst. 91 (3), 226-236.

43. Queiroz, C.; Travassos, A.G.; Studart, E.; Araújo, F.J.B.; Sarno, C.K.; Pinheiro, C.C. (2004). Prevalence of Human Papilloma Virus in HIVPositive and HIV-Negative Patients in the State of Bahia. A Pilot Study. Braz. J. Infect. Dis. 8 (5), 356-362.

44. Rabelo-Santos, S.H.; Zeferino, L.; Villa, L.L.; Sobrinho, J.P.; Amaral, R.G.; Magalhães, A.V. (2003). Human Papillomavirus Prevalence among Women with Cervical Intraepithelial Neoplasia III and Invasive Cervical Cancer from Goiânia, Brazil. Mem. Inst. Oswaldo Cruz. 98 (2), 181-184.

45. Rabkin, C.S.; Biggar, R.J.; Baptiste, M.S.; Abe, T., Kohler, B.A.; Nasca, P.C. (1993). Cancer incidence trends in women at high risk of human immunodeficiency virus (HIV) infection. Int J Cancer. 55, 208-212.

46. Ragin, C.C.R.; Wheeler, V.W.; Wilson, J.B.; Bunker, C.H.; Gollin, S.M.; Patrik, A.L.; Taioli, E. (2007). Distinct distribution of HPV types among cancer-free Afro-Caribbean women from Tobago. Biomarkers. 12 (5), 510-522.

47. Said, H.M.; Ahmed, K.; Burnett, R.; Allan, B.R.; Williamson, A.L.; Hoosen, A.A. (2009). HPV genotypes in women with squamous intraepithelial lesions and normal cervixes participating in a communitybased microbicide study in Pretoria, South Africa. J. Clin. Virol. 44 (4), 318-321.

48. Smith, J.S.; Lindsay, L.; Hoots, B.; Keys, J.; Franceschi, S.; Winer, R.; Clifford, G.M. (2007). Human papillomavirus type distribution in invasive cervical cancer and high-grade cervical lesions: a meta-analysis update. Int. J. Cancer. 121 (3), 621-632.

49. Stevens, M.P.; Garland, S.M.; Tan, J.H.; Quinn, M.A.; Petersen, R.W.; Tabrizi, S.N. (2009). HPV genotype prevalence in women with abnormal pap smears in Melbourne, Australia. J. Med. Virol. 81 (7), 1283-1291.

50. Sun, X.W.; Kuhn, L.; Ellerbrock, T.V.; Chiasson, M.A.; Bush, T.J.; Wright, T.C. Jr. (1997). Human papillomavirus infection in women infected with the human immunodeficiency virus. N Engl J Med. 337, 1343-1349.

51. Tanzi, E.; Amendola, A.; Bianchi, S.; Fasolo, M.M.; Beretta, R.; Pariani, 
E.; Zappa, A.; Frati, E.; Orlando, G. (2009). Human papillomavirus genotypes and phylogenetic analysis of HPV-16 variants in HIV-1 infected subjects in Italy. Vaccine. 27 Suppl 1, A17-23.

52. Tozetti, I.A.; Scapulatempo, I.D.L.; Kawski, V.L.; Ferreira, A.W.; Levi, J.E. (2006). Multiple Types of Human Papillomavirus in Cervical Samples in Women in Campo Grande, MS, Brazil. Braz. J. Infect. Dis. 10 (5), 309-310

53. Trottier, H.; Mahmud, S.; Costa, M.C.; Sobrinho, J.P.; Duarte-Franco, E.; Rohan, T.E.; Ferenczy, A.; Villa, L.L.; Franco, E.L. (2006). Human Papillomavirus Infections with Multiple Types and Risk of Cervical Neoplasia. Cancer Epidemiol Biomarkers Prev. 15 (7), 1274-1280.

54. Villa, L.L.; Ault, K.A.; Giuliano, A.R.; Costa, R.L.; Petta, C.A.; Andrade, R.P.; Brown, D.R.; Ferenczy, A.; Harper, D.M.; Koutsky, L.A.;
Kurman, R.J.; Lehtinen, M.; Malm, C.; Olsson, S.E.; Ronnett, B.M.; Skjeldestad, F.E.; Steinwall, M.; Stoler, M.H.; Wheeler, C.M.; Taddeo, F.J.; Yu, J.; Lupinacci, L.; Railkar, R.; Marchese, R.; Esser, M.T.; Bryan, J.; Jansen, K.U.; Sings, H.L.; Tamms, G.M.; Saah, A.J.; Barr, E. (2006). Immunologic responses following administration of a vaccine targeting human papillomavirus Types 6,11, 16, and 18. Vaccine. 24 (27-28), 5571-5583

55. Watt, A.; Garwood, D.; Jackson, M.; Younger, N.; Ragin, C.; Smikle, M.; Fletcher, H.; McFalane-Anderson, N. (2009). High-risk and multiple human papillomavirus (HPV) infectious in cancer-free jamaican women. Infect. Agent. Cancer. 4 Suppl 1, S11.

56. zur Hausen, H. (1996). Roots and perspectives of contemporary papillomavirus research. J. Cancer Res. Clin. Oncol. 122 (1), 3-13. 